\title{
井戸水を用いる天井放射冷房の実測とそのエクセルギ一解析 MEASUREMENT OF THERMAL ENVIRONMENT AND EXERGY ANALYSIS ON CEILING RADIANT COOLING SYSTEM USING GROUND WATER
}

\author{
淺田秀男*, 武田 仁** \\ Hideo ASADA and Hitoshi TAKEDA
}

\begin{abstract}
The purpose of this study is to utilize the concept of exergy to discuss the meaning of well water 'coolness' applied to a ceiling radiant cooling system. A house in Chiba was equipped with a ceiling radiant cooling system using well water, and with outdoor sun-shading on the South-facing window. We conducted measurements of indoor thermal environment and electric power consumption in the summer of 2001 . The results showed the following: 1. The ceiling radiant cooling system consumed cool thermal exergy from well water and emitted a small part of it as cool radiant exergy from the ceiling radiant panel surface. 2 . When cooling system was used, not only the ceiling radiant panel but also the surrounding walls and floor contributed to the radiant cooling effect by emitting cool radiation exergy. 3 . The well water pump consumed about 56 times more exergy than the ceiling radiant panel and the circulation pump consumed about ten times more exergy.
\end{abstract}

\author{
Keywords : Radiant cooling, well water, exergy analysis, thermal exergy, radiation exergy, \\ thermal environment \\ 放射冷房、井戸水、エクセルギー解析、熱エクセルギー、放射エクセルギー、温熱環境
}

1.はじめに

身近にある自然のポテンシャルを活かし建築環境の調整を行なう

ことは、化石燃料を源とするエネルギー使用量の削隇のみならず、 建築が周囲の自然環境と調和し、持続可能となる上で重要と考える。 井戸水を利用する天井放射冷房システムは、身近にある自然のポテ ンシャルのひとつである井戸水の「冷たさ」を利用するシステムで ある。井戸水を利用するためには、汲上げや循環用のポンプが不可 欠である。一般に、ポンプの電力消費量は、天井放射パネルが室空

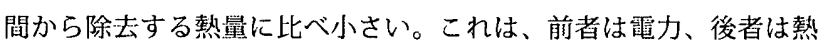
と質の買なるエネルギー同士を直接比較しているからである。 井戸水の「冷たさ」という自然のポテンシャル利用にともなう資 源性の「消費」を明確にすること、また、このような資源性の「消 費」と、電力などの化石燃料を源とする盗源の「消費」とを統一的 に論じることは、従来とは異なる視点からの知見を与えてくれると 考える。

このようなことは、従来のエネルギー保存則に加え、エントロ
ピー増大則を考慮したエクセルギーの概念を用いることで可能とな る。外気温より温度の低い井戸水が持つ冷熱は、物を冷やす能力「冷 エクセルギー」と表現できる ${ }^{1)}$ 。また、天井放射冷却パネル表面に 周囲の熱が吸収される現象は、パネルから冷やす能力である冷エク セルギーが放射されていると捉えられる2)。このことにより、放射 冷房に関わる様々な形態のエネルギーの伝澾現象や、水搬送などの 力学的仕事をすべて「エクセルギー消費」として統一的に表現でき、 天井放射冷房における井戸水や電力などの資源の投入・利用から廃 熱に至る一連の過程を「エクセルギー投入・消費過程」として捉え ることができる。

本研究は、千葉県柏市に建つ住宅 T 邸に備えられている井戸水利 用天井放射冷房システムを対象に、夏期の熱壊境および電力使用量 を実測し、井戸水の「冷たさ」、井戸水搬送用の動力、放射冷却パネ ルからの冷放射といった形態の異なるエネルギーの流れや利用を、 一連のエクセルギー投入・消費過程として明らかにし相互に比較・ 検討することを目的とした。
本諭文は，既に発表している文献11）12）を修正・加籍したものである。

*デルフト工科大学建築学部 客員研究員・博士 (工学)

** 東京理科大学理工学部建築学科 教授 ·工博
NWO (The Netherlands Organization for Scientific Research) Visiting Researcher, Faculty of Architecture, Delft University of Technology (The Netherlands), Dr. Eng.

Prof., Department of Architecture, Faculty of Science and Technology, Tokyo University of Science, Dr. Eng. 
本研究は次のような手順で行なった。まず、T邸を対象に、外付け 日除けにより日射遮へいを行っている場合の、室内温熱環境および ポンプの電力消費黨を実測した。次に、井戸水の伝熱と循環に関わ るエネルギー収支を基に、それぞれに対するエクセルギー収支式を 整理した。それらの式に、実測で得られた室内の空気温度や井戸水 流量・ポンプ電力消費量を利用して、天井放射冷房システムの井戸 水の流れと循環に関わる一連のエクセルギ一投入・消費過程を求め た。最後に、天井放射パネルなどでの冷水の冷エクセルギ一消費と、 波上げ・循環用ポンプでのエクセルギー消費などとの関係について 比較・考察した。

以下では、まず、実測対象住宅であるT邸とそこに備え付けられ ている天井放射冷房システムの概要について述べたのち、2001年夏 期に行なった実測の概要について述べる。次に、天井放射冷房シス テムのエクセルギー解析の概要について述べ、最後に、温熱環境実 測とエクセルギー解析の結果について述べる。

\section{2. 住宅と天井放射冷房の概要}

図 1 は T邸の 1 階と居間部分の平面図である。建物は木造 2 階建て の戸建て住宅で、外壁には $100 \mathrm{~mm}$ のグラスウール、床には $140 \mathrm{~mm}$ のポリスチレンフォーム、空面には透明複層ガラスを用いた高断熱 建築である ${ }^{3)}$ 。図 1 の下部に示した居間が実測対象室で、南面に幅 $3620 \mathrm{~mm} \times 2200 \mathrm{~mm}$ の複層ガラスの空面がある。点線で囲んだ部分 の天井面に放射冷房用のパネルが設置されている。放射パネルは、 長さ $2700 \mathrm{~mm} \times$ 幅 $188 \mathrm{~mm}$ のアルミ製パネルを 36 枚連結（合計 18.3 $\mathrm{m}^{2}$ ) したもので、パネル裏面に取り付けられた配管内に井戸水を循 環させることでアルミ製パネルを冷却し放射冷房を行なう。

図2は、井戸水利用天井放射冷房システムの構成と井戸水の流れの 模式図である4)。図の上部は室空間、右下は深井戸(深さ：66 m)、 左下は井戸水を放流する浸透妌である。まず、深井戸に設置した水 中ポンプで井戸水を地上まで波上げる。次に三方弁で、汲み上げた 井戸水と、天井放射パネルから排出された井戸水とを混合する。こ

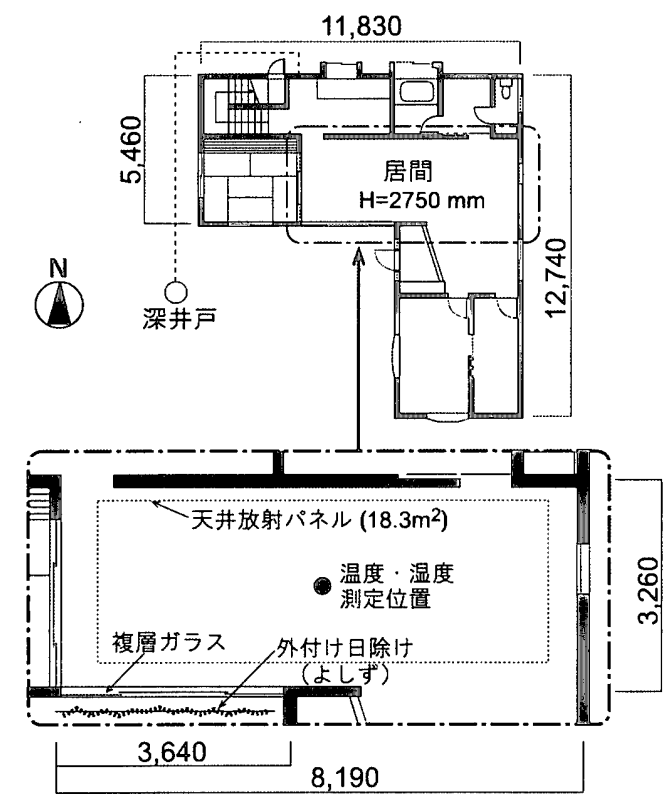

図 1 対象住宅の 1 階平面と天井放射冷房を行なう居間

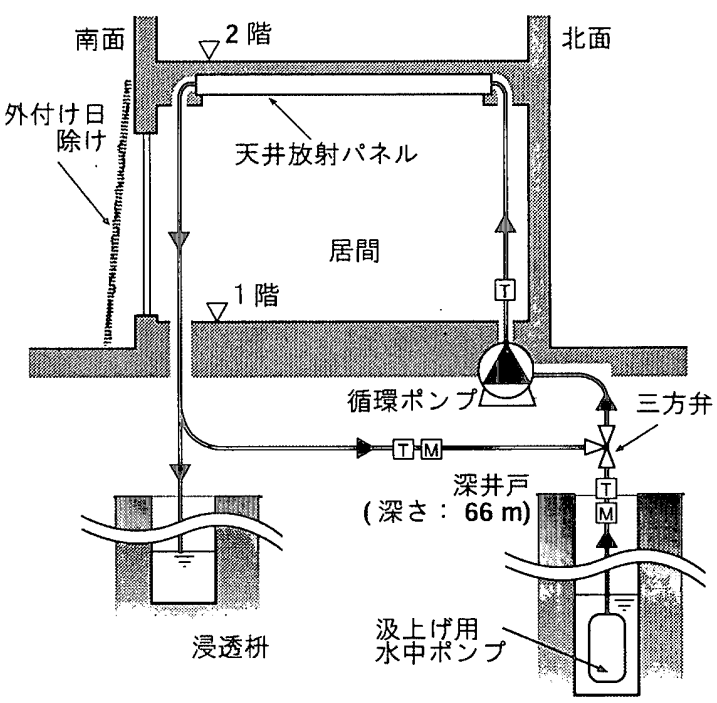

図 2 井戸水利用天井放射冷房システムの構成と井戸水の流れ $\mathrm{T}:$ 水温計、M：流量計

れは、天井放射パネルに送る井戸水の温度を任意の設定温度に調節 するためである。三方弁での混合量は、天井放射パネル入口側の配 管に取り付けられた温度センサーによって制御されている。三方弁 で温度調節された井戸水は、循環ポンプを用いて天井放射パネルに 送られる。放射冷房運転中の放射パネルへの送水流量は、約 $0.32 \mathrm{l} / \mathrm{s}$ でほぼ一定である。天井放射パネル内を循環してアルミパネルを冷 やすことにより温度が上界した井严水はパネルから排出され、一部 は三方弁へ、残りは浸透枅へ放流される。

\section{3. 実測概要}

図1に示した居間を対象に、室内温熱罯境およびポンプ電力消費 量に関する実測を行なった。日射遮へいなどのパッシブ手法によっ て冷房の負荷をできるだけ小さくし、残った負荷を、できるだけ高 い温度の泠水を利用して放射冷房を行なうことを想定し、放射冷房 を運転中は常に空面の外側に䉪簧を設置することにし、天井放射パ ネルの表面設定温度を $22^{\circ} \mathrm{C}$ とした。

温熱環境実測は、2001年8月下旬から9月中旬にかけて行なった。 表 1 は、実測項目である。実測項目は、屋外の日射量・外気温、室 内の空気温・グローブ温、床・空ガラスの表面温度、三方弁や放射 パネルを出入りする冷水の水温、汲上げ用と循環用ポンプの電力消 費量で、合計約 30 点を 1 分間隔で連続測定した。床面・天井表面温、 室内空気温度・グローブ温度は、図 1 の下部の居間中央の○印で示 した位置で計測した。また泠水の水温と流量は、それぞれ図2中の $\mathrm{T}$ およびMと示した位置で計測した。なお、天井放射冷房は 10 時〜 16 時まで運転し、外付け日除けも同じ時間带のみ取り付けた。なお、8 月末から9月にかけては天候が不順な日が多かったので解析から除 き、比較的外気温が高く日射量が大きかった 8 月 24 日のデータを用 いることにした。

\section{4. エクセルギー解析の概要}

一般に、エネルギーの移動または形態変化のある部位・機器でエ 
表 1 計測項目の概要

\begin{tabular}{|c|c|c|}
\hline 場所 & 計測項目 & 計測点数 \\
\hline 屋外 & 外気温、水平面日射量 & 計2点 \\
\hline \multirow[t]{6}{*}{ 室内 } & 室温（FL+0.4, 0.8, 1.2, 1.6, 2.0, 2.4, 2.75m） & 計7点 \\
\hline & 表面温度（ガラス内外表面、床面、天井面） & 計9点 \\
\hline & グローブ温（FL+1.2m） & 1点 \\
\hline & 相対湿度、気流速度、床下表面温、床下空気温 & 計4点 \\
\hline & 上下方向の放射熱伝達量 & 1点 \\
\hline & 床下空気温 & 1点 \\
\hline \multirow[t]{2}{*}{ 配管内 } & 水温（井戸水、三方弁の入口12ヶ所） & 計3点 \\
\hline & 流量（井戸水汲上げ、三方弁入口側） & 計2点 \\
\hline ポンプ & 電力消費（水中ポンプ、循環ポンプ） & 計2点 \\
\hline
\end{tabular}

クセルギーは消費される。そこで、まず天井放射冷房システム内で、 エネルギーの移動・形態変化のある部位・機器をひとつひとつサブ システムと定義した。次に、各サブシステムごとにエネルギー・エ ントロピー収支式を立て、両者よりエクセルギー収支式を導きエク セルギー消費を求めた ${ }^{4)}$ 。あるサブシステムからのエクセルギー出 力は、別のサブシステムへの入力になるので、サブシステムごとの エクセルギー投入・消費・出力を連ね合わせれば、天井放射冷房シ ステム全体のエクセルギー投入・消費過程が求められる5)。ここで 定義したサブシステムは、図 2 を参考に井戸水の流れの源から順に、 深井戸中の汲上げ用水中ポンプ (以下、水中ポンプと記す)、三方弁、 冷水循環用ポンプ（以下、循環ポンプと記す）、天井放射パネルの 4 つである。水中ポンプと循環ポンプは、ポンプに電力を投入して井 戸水を汲み上げたり循環させるといった力学的仕事を行なっている。 また、三方弁は異なる温度の水の混合による熱移動、放射パネルの 低温の冷却面には室内空間の熱が放射および対流の形で移動してい る。

天井放射パネルを例としてエネルギー・エントロピーおよびエク セルギー収支式を付録 1）に示す。なお、天井放射パネルや床・壁 表面から放たれる長波長放射のエクセルギーの計算は、文献 6) 7)、また、放射冷房を行なう室空間のエクセルギー解析は、文献8） 9）10）を参考にした。

\section{5. 結果及び考察}

図3の上図は解析に用いた 8 月 24 日の外気温、下図は屋外水平面 日射量の時刻変化である。外気温は $24 \sim 31^{\circ} \mathrm{C}$ 、水平面日射量は 200 〜 $800 \mathrm{~W} / \mathrm{m}^{2}$ 程度であった。12時以降はやや雲が多かったので、日射 量が全体的に小さく、かつ変動が大きくなっている。

\section{5-1 温熱環境}

図 4 は、室内の空気温・グローブ温・相対湿度の実測值とSET*の 計算値の時刻変化を示したものである。横軸は時刻、左縦軸は温度、 右縦軸は相対湿度[\%]である。空気温・グローブ温は床上 $1.2 \mathrm{~m}$ の高 さの值である。SET*の計算は、勂気温・グローブ温・相対湿度およ び室内気流速度の実測值を用い、着衣量を 0.45 clo、代謝量を 1.0 met と仮定して求めた。その際、人体に吸収される日射量は無視した。

$10 \sim 16$ 時の天井放射冷房運転中、床上から $1.2 \mathrm{~m}$ の空気温度は 28 $\sim 28.7^{\circ} \mathrm{C}$ 程度で、小刻みに上下変動しているものの放射冷房運転開 始時から終了時までの温度上昇は $1{ }^{\circ} \mathrm{C}$ 末満であった。一方、同じ高さ のグローブ温は天井放射冷房の効果により約 $27.5 \sim 28^{\circ} \mathrm{C}$ と常に筀気

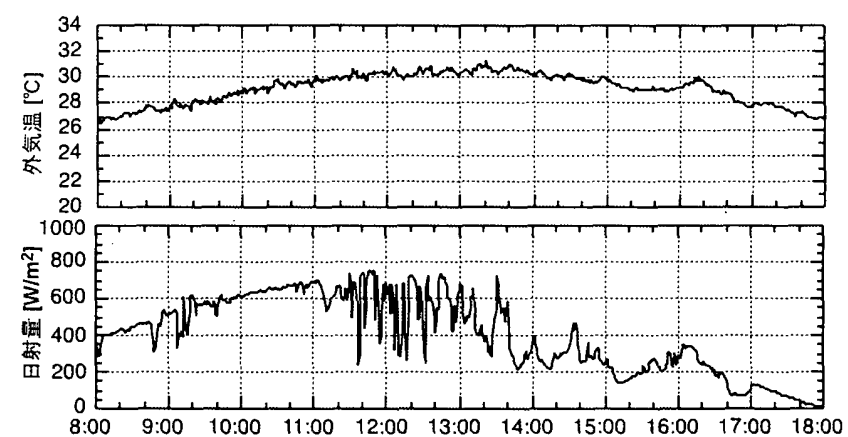

図 3 実測日の外気温と日射量

温より約 $1{ }^{\circ} \mathrm{C}$ 低くなっている。このときのSET*の計算値は $28.5 〜 29$

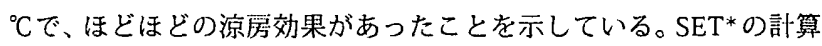
值は、どの時刻においても空気温よりわずかに高くなっている。こ れは、室内の相対湿度が約 $75 \%$ とやや高かったことが影響している と考えられる。

図 5 は、ガラス面室内側表面温・休表面温および天井表面温の時 刻変化である。比較のため、図 4 に示した床上 $1.2 \mathrm{~m}$ の空気温も図中 に記した。10〜 16時のガラス面の室内倒表面温度は、10〜 16時の 間 $29 \sim 32^{\circ} \mathrm{C}$ と温度上昇が比較的小さい。10〜 12 時ごろに温度上昇 が小いのは、居間東側の母屋の影響で直達日射が空面に直接入射し ないため、12 時以降に温度上昇が小さいのは日射量がやや小さく、 かつ、外付け日除けを用いて日射遮へいを行なったことによると考 えられる。床表面温度は $10 \sim 16$ 時の間約 $27^{\circ} \mathrm{C}$ でほぼ一定で、常に 空気温より約 $1^{\circ} \mathrm{C}$ 低くなっている。このことは、放射熱伝達により天 井放射パネルが床表面から直接熱を受け取っている、すなわち床表 面から熱を除去していることを示している。天判表面温度は上下 $1{ }^{\circ} \mathrm{C}$ 程度の小刻みな変動があるが、平均するとほぼ $23^{\circ} \mathrm{C}$ 程度であった。

以上より、天井表面温度設定 $22^{\circ} \mathrm{C}$ (実際の表面温度は約 $23^{\circ} \mathrm{C}$ ）と 比較的高温であるにもかかわらず、天井放射冷房運転中は、空気温

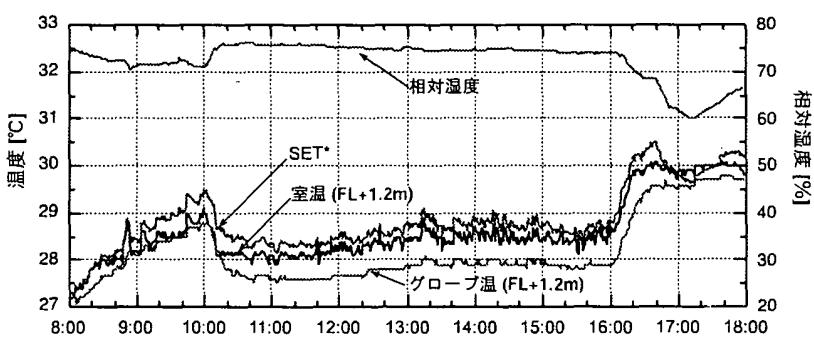

図 4 室温・グローブ温・相対温度と SET*の時刻変化

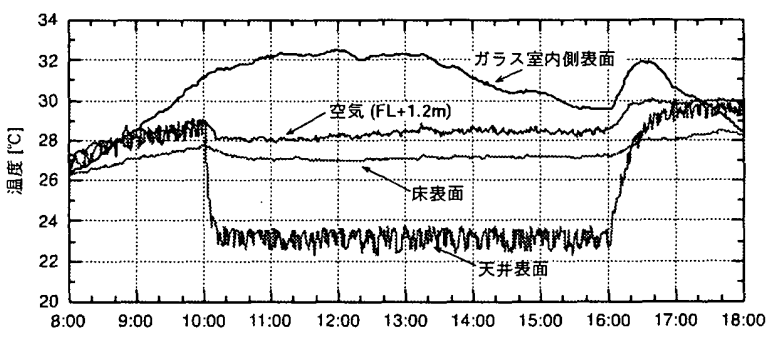

図 5 ガラス表面温・本表面温・天井表面温の時刻変化 


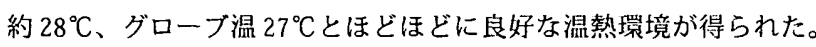
これは、天井放射冷房および外付け日除けによる日射遮へいの効果 に加え、13時以降の屋外日射量が比較的小さかったことも少なから ず知与したためと考える。

次に、図 4・5に示した温熱環境形成に際し、井戸水の「冷たさ」 や電力などの資源性がシステムのどの部位で、どれだけ「消費」さ れたのかを明らかにし相互に比較するため、天井放射冷房システム 全体のエクセルギー投入・消費過程を求めた。以下ではその結果に ついて述べる。

5ー2 エクセルギー解析

5-2-1 井戸水利用と搬送のエクセルギー投入・消費過程 図 6 は、屋外日射䡒が比較的大きかった 13 時における天井放射冷房シ ステム全体のエクセルギー投入・消費過程の計算結果である。図中 の口内の数值は、それぞれの部位または機器でのエクセルギ一消費 $[W] 、 \triangle の$ 隣の数值は配管内の冷水が持つ冷エクセルギー $[\mathrm{W}] 、$ 天井 放射パネルから出ている白报きの波線矢印は放射の冷エクセルギー、 弧になった白报き矢印は天井放射パネルと室内空気との対流熱伝達 の冷エクセルギーを示している。この時刻における外気温は約 $30^{\circ} \mathrm{C} 、$

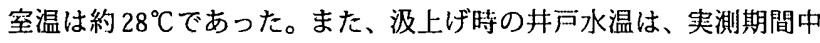
約 $18^{\circ} \mathrm{C}$ でほぼ一定であった。なお、ここでは簡単のため空面から室 内に入射する日射はすべて、天井面以外の床や壁面に吸収されると 假定した。以下では、井戸水の流れの順にそれぞれの部位・機器に おけるエクセルギー投入・消費について述べる。

まず、井戸水汲上げ用水中ポンプに着目する。水中ポンプでは、 $66 \mathrm{~m}$ の深さにある井戸水を $0.06 \mathrm{l} / \mathrm{s}$ の流量で地上まで汲上げるため に、投入された電力のエクセルギー 435 Wのうち 398 Wが消費され ている。これは、循環ポンプにおける消費 $(66 \mathrm{~W})$ の約 6 倍 (=398 $\div 66)$ 、天井放射パネルにおける消費 $(7 \mathrm{~W})$ の約 56 倍 (=398 $\div 7)$ と他のエクセルギ一消費と比べ著しく大きい。投入された電力のエ

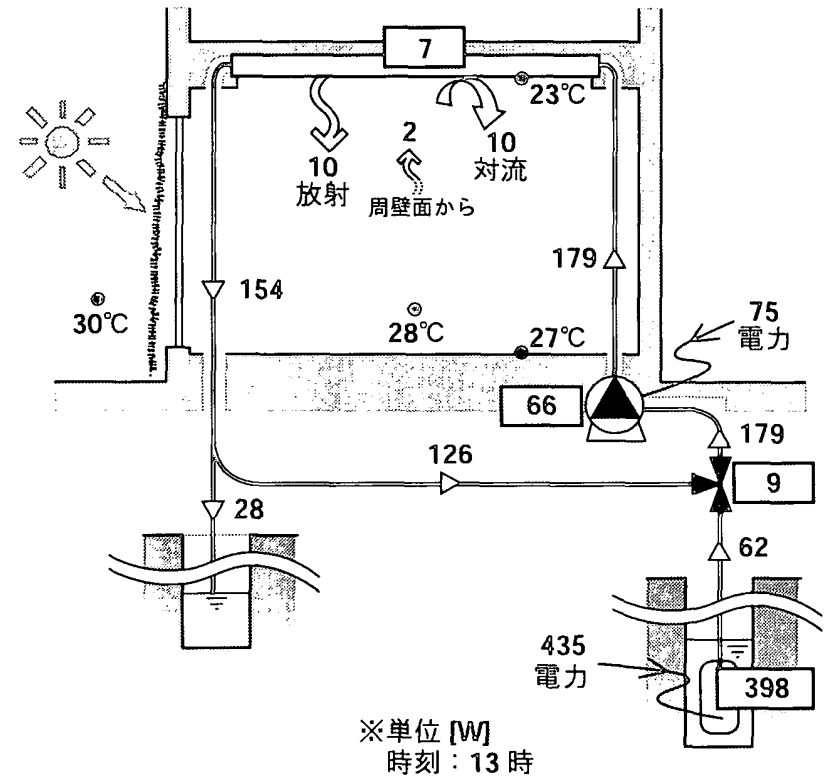

図 6 天井放射冷房のエクセルギー投入・消費過程 口内の数值 : エクセルギ一消費 [W] $\triangle$ 隣の数值：冷水の冷エクセルギー [W]
クセルギーと消費との差 37 W (=435-398)は、井戸水に加えられた重 力の位膡エネルギー（=エクセルギー）である。

次に、汲み上げられた杫戸水が送られる三方弁について見てみる。 三方弁には、波上げられた直後の井戸水（約 $18{ }^{\circ} \mathrm{C} 、 0.06 \mathrm{\ell} / \mathrm{s}$ ) の持 つ冷エクセルギー $62 \mathrm{~W}$ と、天井放射パネルからの還り水 (約 $22{ }^{\circ} \mathrm{C}$ 、 $0.26 \mathrm{l} / \mathrm{s})$ の持つ冷エクセルギー $126 \mathrm{~W}$ と合わせて $188 \mathrm{~W}\left(21^{\circ} \mathrm{C} 、 0.32\right.$ 凡/s）が入っている。後者の方が外気温との温度差が小さいにも関わ らず冷エクセルギーが大きいのは、後者の流量が前者の 4 倍以上だ からである。三方弁で異なる温度の水を混合することにより $9 W$ の 冷エクセルギーが消費される。その結果、179 W (=62+126-9) の冷 エクセルギーを持つ水が三方弁から出てきている。

179 Wの冷エクセルギーを持つ水は、循環ポンプで 66 Wの電力の エクセルギーを消費することにより、放射パネル内を循環するため の運動エクセルギー（=75-66）を得ている。このエクセルギーは、 冷水が配管内を循環する際に管壁との摩擦などにより消費される。 ただし、ここでは主として冷水の持つ冷エクセルギーの消費過程に 着目しているので、図 5 中の循環ポンプから出ている冷水のエクセ ルギー 179 Wに、運動のエクセルギーの分は加えていない。

天井放射パネルに着目すると、パネルには $179 \mathrm{~W}$ の冷エクセル ギーを持つ冷水と、 $2 \mathrm{~W}$ の放射の冷エクセルギーがパネルを取り囲 む周壁面と床表面とから入射している。これらのうちの $7 \mathrm{~W}$ がパネ ル内部で消費されることで、パネル表面から放射の祫エクセルギー $10 \mathrm{~W}$ と、対流の冷エクセルギー $10 \mathrm{~W}$ が放たれている。残りの冷エ クセルギー $154 \mathrm{~W}(=179+2-7-10-10)$ は、パネルから排出される冷水に 伴ってパネルから出て来ている。

外気温や日射量が図 6 のそれと比べ小さい時刻のエクセルギー投 入・消費がどのようであったかを天井放射パネルを例に示す。

図 7 は、天井放射パネルのエクセルギー消費と、放射パネルを出 入りする冷水の冷エクセルギーとの時刻変化である。このとき放射 パネルに入る・出る冷水の温度はそれぞれ約 $21^{\circ} \mathrm{C}$ 拉よで約 $22^{\circ} \mathrm{C} て ゙ 、$ 10〜16時の間ほぼ一定である。放射パネルを出入りする冷水の冷工 クセルギーは、水温がほぼ一定であるにもかかわらず、13時半ごろ を最大として大きく增減している。これは、水温一定の冷水が外気 環境に対して持っている「冷たさ」という資源性が、外気温との温 度差が大きくなることにより相対的に大きくなることを示している。

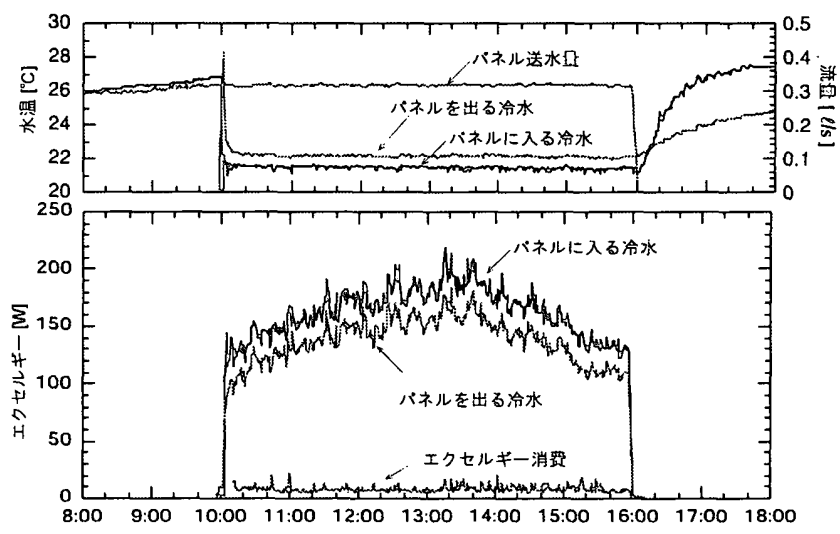

図 7 天井放射パネルを出入りする冷水の冷エクセルギー とエクセルギー消費 
一方、10〜16時に扔ける天朴放射パネルのエクセルギ一消費は、約 7〜8Wとほぼ一定である。これは、図 4 や 5 に示した室内温熱䘫境 は、天井放射パネルで 7 8Wの冷エクセルギーを消費し続けるこ とで維持されていたことを示している。

ここで、天杫パネルを出入りする冷水の熱量（エネルギー）の差、 すなわち天井放射パネルが室内から除去した熱曾は、流量を $0.32 \mathrm{lls}$ 、天朴パネル出入口の冷水の温度差を約 $1{ }^{\circ} \mathrm{C}$ とすると約 $1300 \mathrm{~W}$ であ る。1300 W という熱エネルギーの值と比べると、図6に示した波上 げ及び循環ポンプへの投入電力（ $435 \mathrm{~W}$ と 75 W）は、それ程大きく は見えない。しかしながら、図6に示した天井放射パネルでのエク セルギー消費 $(7 \mathrm{~W})$ と、水中・循環ポンプのエクセルギ一消費 (そ れぞれ $398 \mathrm{~W}$ と $66 \mathrm{~W})$ とを比べることで、雨ポンプのエクセルギー 消費が全体の中で著しく大きいことが明確になった。

最後に、天井放射パネルから排出された冷水に伴う冷エクセル ギー154Wのうち、126 W は三方异へ、残りの $28 \mathrm{~W}$ は漫透妌に放 流されている。結局、汲上げ時に井戸水が持っていた冷エクセル ギー 62 Wの約半分に相当する冷エクセルギーは、消費されることな く地中へ唅てらている。

5-2-2 床表面での放射の冷エクセルギー消費 天井放射パネ ルから放たれた放射の泠エクセルギーは、床や壁面などに入射し消 費される。ここでは一例として、床表面でのエクセルギ一投入・消 費を示す。

図 8 は、天井放射パネルからの放射の冷エクセルギーが床表面に 入射して消費される模式図である。時刻は図 6 と同じ 13 時である。 白抜きの矢印は冷エクセルギー、黑塗りの矢印はものを温める能力 を持つエクセルギーである。また、波形の矢印は放射エクセルギー、 弧になった矢印は対流のエクセルギーである。口内の数值はエクセ ルギー消費である。

床表面には、㷅面を透過した日射（短波唇放射）エクセルギーの うちの $14.3 \mathrm{~W}$ 注1）と空ガラス表面からの放射（長波長放射）のエク セルギー 0.2 Wが入射している。雨者ともに床面を温める能力を

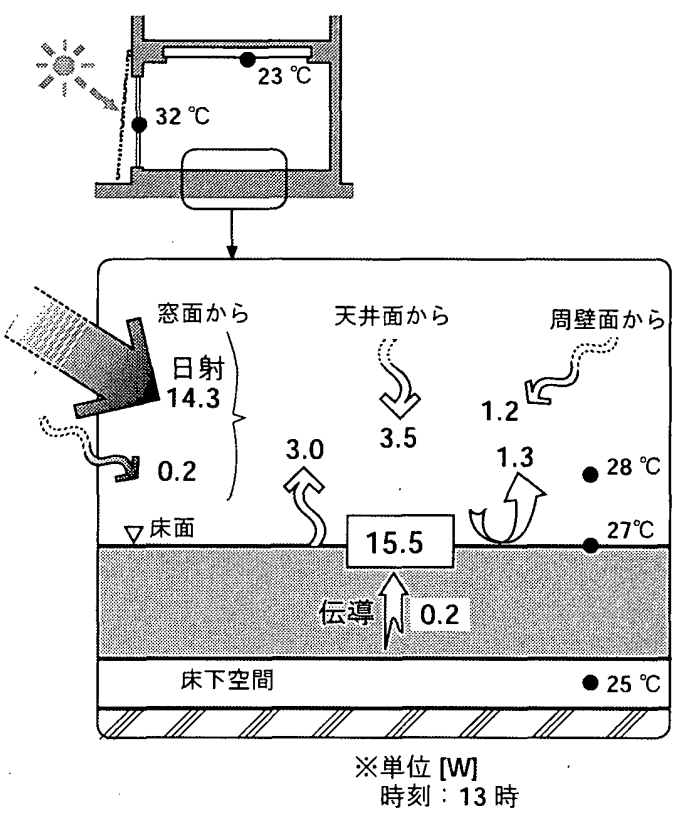

図 8 床表面におけるエクセルギー投入・消費の様子
持っている。日射は床表面に入射し吸収されることで短波長放射か ら熱に変化する。この変化に伴いすべての日射エクセルギーが消費 される。空ガラス表面からの長波長放射も同様に床表面に吸収され 熱になることで全て消費される。一方、床表面では、日射吸収によ る熱と、空ガラスからの長波長放射を吸収したことによる熱を床表 面から除去するために、天井放射パネル执よび周壁面からの放射の 冷エクセルギー $3.5 \mathrm{~W}$ と $1.2 \mathrm{~W}$ 注2）の一部が消費される。したがっ て、合計 15.5 W0エクセルギーが床表面で消費されている。 $15.5 \mathrm{~W}$ の内の $14.3 \mathrm{~W}$ は日射エクセルギーを消費したことによるもの、残り が天井放射パネルと周壁面からの放射の冷エクセルギーを消費した ことによるものである。日射の熱を床表面から取り除く際に入射し た放射の冷エクセルギーのすべてが消費されなかったことから、床 表面からは放射の冷エクセルギー3.0Wと対流熱伝達による冷エクセ ルギー $1.3 \mathrm{~W}$ 放っている。このことは、外付け日除けなどを用いて 室內に入射する日射を小さくして床表面での日射エクセルギー消費 を小さくすることは、床表面から放たれる冷エクセルギーを大きく し、冷房効果を高める上で重要であることを示している。

\section{6. まとめ}

本研究では、井戸水を利用する天井放射冷房システムを備えた住宅 を対象に、夏期の温熱環境扣よびポンプ電力消費に関する実測を行 ない、天井放射冷房における井戸水や電力などの資源の投入 - 利用 から廃熱に至る一連のエクセルギー投入・消費過程を明らかにし相 互に比較・考察した。その結果、以下のことが分かった。

1) 井戸水利用天井放射冷房システムは、水中ポンプと循環ポンプ で電力のエクセルギーを消費することで、冷エクセルギーを持つ 井戸水を汲上げ循環させている。井戸水の冷エクセルギーは、一 部が三方弁で、一部が天井放射パネルで消費される。これらの消 費の結果として天井放射パネル表面からは冷エクセルギーが放射 および対流の形で室空閜に放たれている。システム内で消費され なかった冷水の冷エクセルギーは、そのまま放流柳に捨てられて いる。

2）井戸水を汲上げるために水中ポンプで消費される電力のエクセ ルギーは、天井放射パネルなどでの冷水の冷エクセルギー消費と 比べ著しく大きく、かつ、天井放射冷屏システム内で最大となっ ている。

3）天井放射パネルから放たれた放射の冷エクセルギーは、室内表 面を冷却する際に消費される。例えば、床表面では、日射が吸収 され熱に変わることにより日射エクセルギーのほぼすべてが消費 され、その結果生じた熱を床表面から除去するため、天井面及び 周壁面からの放射の冷エクセルギーの一部が消費される。結局、 床表面でのエクセルギー消費は日射によるものが大部分を占める ている。このことは、日射遮へいなどを行ない俰表面での日射工 クセルギー消費を小さくすることは、床表面から放たれる冷エク セルギーを大きくし、放射の冷エクセルギーによる冷房效果を高 める上で重要であることを示している。

4）井戸から汲上げた冷水の冷エクセルギーの約半分に相当する冷 エクセルギーは、システム内で消鿓されることなく放流される冷 水にともない地中に捨てられている。 


\section{謝辞}

本論文の大部分は、筆者が当時所属していた東京埋科大学理工学 部建築学科で行ない、解析の一部はNWO (The Netherlands Organization for Scientific Research) 協力を得 $て$ Delft University of Technology , Faculty of Architecture (The Netherlands)で行ないまし た。また、本論文執筆に際し宿谷昌則教授（武蔵工業大学環境情報 学部)に貴重なご意見をいただきました。高橋達氏（福岡工業大学・ 専任講師)には、放射の冷エクセルギーの流れの方向と消費される 場所との関係について数々の助言をいただきました。Elisa C. Boelman 氏（デルフト工科大学・講師）には、本論文全般に対する ご意見・助䓂を頂きました。夏期実測およびデータ整理に際し、奈 良憲晃さん（当時、東京理科大学理工学部卒論生）に多くのご協力 を得ました。記してこれらの方々に謝意を表します。

記号表（式(A1) (A4)に対态)

$A_{i} \quad:$ 面 $i$ (ここでは天井面) の面積 $\left[\mathrm{m}^{2}\right]$

$A_{j} \quad:$ 面 $j(j=1,2, \ldots, i, \ldots, N)$ の面積 $\left[\mathrm{m}^{2}\right]$

$a_{j i}$ :面jから放たれ面沉吸収される放射の割合(放射吸収係数) [-]

$C_{p}:$ 水の比熱 $[\mathrm{J} /(\mathrm{kg} \cdot \mathrm{K})]$

$h_{c i}$ : 天井表面と室内空気との対流熱伝達率 $\left[\mathrm{W} /\left(\mathrm{m}^{2} \cdot \mathrm{K}\right)\right]$

$R_{i}$ : 天井面に入射する日射エネルギー $\left[\mathrm{W} / \mathrm{m}^{2}\right]$

$s_{g r p}$ : 天井放射パネルでのエントロピー生成 [W/K]

$s_{R i}:$ 日射に伴うエントロピー $\left[\mathrm{W} /\left(\mathrm{m}^{2} \cdot \mathrm{K}\right)\right]$

$T_{j} \quad:$ 面 $j$ の表面温度 $[\mathrm{K}]$

$T$, : 室温[K]

$T_{\text {win }}$ : 天井放射パネルに入る井戸水の温度 $[\mathrm{K}]$

$T_{\text {wout }}$ : 天井放射パネルから出てくる井戸水の温度 $[\mathrm{K}]$

$V$ : 天井放射パネルに入る（出る）井戸水の流量 $\left[\mathrm{m}^{3} / \mathrm{s}\right]$

$\bar{\varepsilon}_{j}\left(\bar{\varepsilon}_{i}\right)$ : 面 $j$ (面 $i$ ) の平均放射率 [-]

$\rho_{w}:$ 水の比重 $\left[\mathrm{kg} / \mathrm{m}^{3}\right]$

$\sigma \quad:$ シュテファン・ボルッマン定数 $\left[\mathrm{W} /\left(\mathrm{m}^{2} \cdot \mathrm{K}^{4}\right)\right]$

\section{参考文献}

1) 缩谷昌則：温エクセルギーと冷エクセルギーに関する考察、日 本建築学会大会学術講演梗概集 (近畿)、pp. 453-454、1996 年 9 月。

2) 高橋達、近藤大翼、伊澤康一、宿谷昌則 : 放射エクセルギーの 計算方法、日本建築学会大会学術講演梗概集 (東北)、pp. 487 $488 、 2000$ 年 9 月。

3) 武田仁: 井戸水利用天井輻射冷暖房システムの研究 その1 シ ステムおよび建物の概要、日本建築学会大会学術講演梗概集 (中国)、pp. 911-912、1999 年 9 月。

4) 武田仁、山本未生 : 井严水利用天井曧射冷房に関する研究一快 適性と省エネルギー性の検証一、日本建築学会技術報告集 第 11 号、pp. $139 \sim 144 、 2000$ 年 12 月。

5 ）浅田秀男、宿谷昌則 : 昼光照明のエントロピー・エクセルギー 解析、日本建築学会計画系論文集 第 461 号、pp. 43 50、1994 年 7 月。

6）宿谷昌則：外壁外表面のエントロピー・エクセルギー収支、日 本建築学会大会学術講演会梗概集 (東海)、pp. 429 430、1994 年 9 月。

7）高橋達、近藤大翼、伊澤康一、宿谷昌則：放射エクセルギーの
計算方法、日本建築学会大会学術講演梗概集 (東北)、pp. 487 $488 、 2000$ 年 9 月。

8 ）宿谷昌則：光と熱の建築環境学、丸善、pp. $90 \sim 100 、 1993$ 年。

9 ）近藤大翼、小海隆裕、伊澤康一、湯沢咉子、高橋達、宿谷昌則 : 住宅の放射冷房に関する実測とエクセルギー解析、日本建築学 会大会学術講演梗概集（東北）、pp. $489 \sim 490 、 2000$ 年 9 月。

10）森一顕、伊澤康- - 直井隆行、高橋達、宿谷昌則：放射冷房パ ネルによる採冷の研究 (その1. パネルの自作と実测絬果)、日 本建築学会大会学術講演梗概集 (関東)、pp. 457〜 458、2001年 9 月。

11）宿谷昌則：光と熱の建築環境学、丸善、pp. $90 \sim 100 、 1993$ 年。

12）淺田秀男、武田仁：井戸水を用いる天井放射冷房に関する実測 とエクセルギー解析、日本建築学会大会学術講演梗概集（北 陸)、2002 年 8 月。

13)H. ASADA, H. TAKEDA: Thermal Environment and Exergy Analysis of a Ceiling Radiant Cooling System, Sustainable Building 2002, International Conference (Oslo, Norway), No. 651, September 23252002 .

注 1 ) 床表面に入射する日射エクセルギーは、以下のようにして求 めた。まず、屋外水平面日射量を宇田川らによる方法で直散分 離したのち、太陽高度・方位角の計算值から鉛直面に入射する 直達および天空日射を時々刻々求めた。次に、外付け日除けと 複層ガラスとを組み合わせた空面の総合透過率の計算値と、鉛 直面に入射する直達および天空日射の計算値とから室内に透過 する日射量を求めた。床表面に入射する日射量は、公面を一様 拡散面と仮定し、空面と床面との形態係数とから求めた。この 日射に含まれるエクセルギ一は、文献10）に示した方法を用い て求めた。ただし、空面の総合透過率を求める際、蕫筫の直達 および天空日射に対する光学特性は、スラット角 $60^{\circ}$ の水平ブ ラインドで代用した。これは、墇筫の日射遮へい特性の詳細を 求めるのは本研究の主旨外であること、また、このように仮定 して求めた日射量の值を用いても、図8 から導き出した結論は 概亦わらないと考えるからである。

注 2 ) 周壁面から床面に入射する放射の冷エクセルギーは、以下の 様にして求めた。実測対象となった居間では、どの面の平均放 射率も $0.85 \sim 0.9$ 程度である。この場合、放射率を 1.0 と仮定し、 放射吸収係数の代わりに形態係数を用いても、大きな誤差は生 じないと考えられる11)ので、放射吸収係数の代わりに形態係数 を用いて放射に関する伝熱計算を行なうことにした。まず、床 表面におけるエネルギー収支式を付録 1 と同様な方法で導いた。 床表面に入るエネルギーは、空面からの日射、空面からの長波 長放射、天井面执よび周壁面からの長波長放射である。また、床 面から出るエネルギーは、床表面からの長波長放射と、床表面 と室内空気との対流による熱伝達、床下空間との伝導による熱 伝達成分である。床表面に入射し吸収される日射は注 1 ）の方 法を用いて与え、天井面から麻面に入射する長波長放射は、天 井表面温度と、天井面と床面との形態係数とから求めた。また、 床下瑩間との伝導による熱伝達は、床の熱買流率（約 $0.24 \mathrm{~W} /$ $\left(\mathrm{m}^{2} \cdot \mathrm{K}\right)$ ) と椺表面温度と床下空間側の表面温度とから求めた。 
したがって、床表面におけるエネルギー収支式中では、周壁面 からの長波長放射成分のみが末知数なので収支式を解くことで 求められる。この長波長放射エネルギーが、天井面・空面扔よ び床面以外の平均表面温度 $T_{m}[\mathrm{~K}]$ の周壁面から放射されると仮 定して $T_{m}$ を求めたのち、周壁面からの放射の冷エクセルギーを 付録 1 の $(\mathrm{A} 1) \sim(\mathrm{A} 3)$ と同様な方法で求めた。

\section{付録 1}

図A1は、天材放射パネルのエネルギーの出入りを模式的に示した ものである。簡単の為、天井放射パネルの天井裏側の面は完全に断 熱されているとし、アルミ製の放射パネルの熱容量は考えないこと にした。まず、天井放射パネルには井户水 $V\left[\mathrm{~m}^{3} / \mathrm{s}\right]$ が温度 $T_{\text {win }}[\mathrm{K}]$ で 入り $T_{\text {wout }}[\mathrm{K}]\left(T_{\text {win }}<T_{\text {wout }}\right)$ で出てくるとすると、エネルギー収支式 は以下の様になる。

$$
\begin{aligned}
A_{i} R_{i} & +C_{P} \rho_{w} V\left(T_{w i n}-T_{O}\right)+\sum_{j=1}^{N} A_{j} a_{j i} \bar{\varepsilon}_{j} \sigma T_{j}^{4} \\
= & C_{P} \rho_{w} V\left(T_{\text {wout }}-T_{O}\right)+A_{i} h_{c i}\left(T_{i}-T_{r}\right)+A_{i} \bar{\varepsilon}_{i} \sigma T_{i}^{4}
\end{aligned}
$$

ここで、 $A_{i}$ : 面 $i$ (天井面) の面積 $\left[\mathrm{m}^{2}\right] 、 R_{i}$ : 天井面に入射する日射 $[\mathrm{W}] 、 C_{p}$ : 水の比熱 $[\mathrm{J} /(\mathrm{kg} \cdot \mathrm{K})] 、 \rho_{\mathrm{w}}:$ 水の比重 $\left[\mathrm{kg} / \mathrm{m}^{3}\right] 、 V:$ 井戸水流量 $\left[\mathrm{m}^{3} / \mathrm{s}\right] 、 A_{j}$ : 面 $j\left(j=1,2, \ldots, i_{1} \ldots, N\right)$ の面積 $\left[\mathrm{m}^{2}\right] 、 a_{j i}$ : 面 $j$ から放たれ 面 $i$ (天井面) に吸収される放射の割合（=放射吸収係数）[-]、 $T_{j}$ : 面 $j$ 表面温度 $[\mathrm{K}] 、 \sigma:$ シュテファン・ボルッマン定数 $\left[\mathrm{W} /\left(\mathrm{m}^{2} \cdot \mathrm{K}^{4}\right)\right] 、 \bar{\varepsilon}_{j}$ : 周壁面 $j$ の平均放射率 $[-] 、 T_{r}$ : 室温 $[\mathrm{K}] 、 h_{c i}$ : 天井表面と室内空気と の対流熱伝達摔 $\left[\mathrm{W} /\left(\mathrm{m}^{2} \cdot \mathrm{K}\right)\right]$ 。

(A1)式左辺第 1 項は、天井面に入射する日射、第 2 項が放射パネル に入る井戸水が温度 $T_{O}[\mathrm{~K}]$ の環境に対して持っている熱エネルギー、 第 3 項は周壁面から発せられる長波長放射のうち天井表面に入射す る成分である。また、右辺第 1 項は放射パネルから排出される井戸 水が温度 $T_{O}[\mathrm{~K}]$ 環境に対して持っている熱エネルギ一、第 2 項は 放射パネル表面と室空気との対流により伝達される熱エネルギー、 第 3 項は天井面から放たれる長波長放射である。

ところで、文献 6）7）で述べられているようにエクセルギーは、 エネルギーや物質が環境に対してどれだけ拡散できるかを示す概念 で、環境の温度や濃度を基準にした物理量である。そのため、エク セルギー収支式を導く過程で必要となるエネルギー収支式やエント ロピー収支式においても、状態量の項を環境基準にしたかたちに変

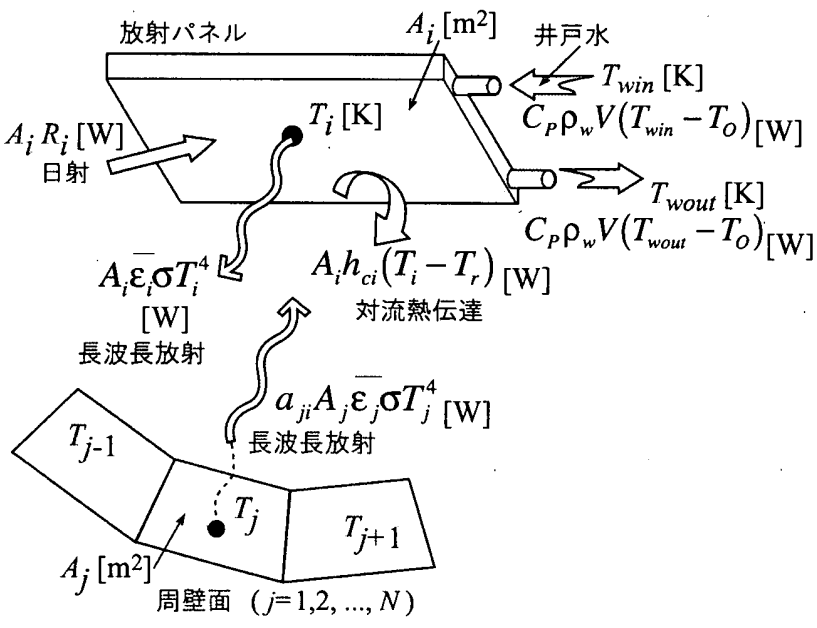

図 A1 放射パネルのエネルギ一収支の模式図
える必要がある。井户水のもつ等エネルギー（(A1)式の左辺第 2 項 とと石辺第 1 項）は既に環境温度 $T_{0}$ 基準の形になっているので、長 波長放射エネルギーの項（左辺と右辺の第 3 項）を環境基準の形に する。まず、(A1)式左辺第 3 項に放射O相反則 $\left(A_{j} a_{i j} \bar{\varepsilon}_{j}=A_{i} a_{i j} \bar{\varepsilon}_{i}\right)$ を適用し整理したのち、(A1)式の両辺に $\left(-A_{i} \bar{\varepsilon}_{i} \sigma T_{0}^{4}\right)$ を扣えて放射工 ネルギーの項を噮境温度 $T_{O}$ を基準にした形にする6)。

$$
\begin{aligned}
A_{i} R_{i} & +C_{P} \rho_{w} V\left(T_{w i n}-T_{O}\right)+A_{i} \bar{\varepsilon}_{i} \sigma \sum_{j=1}^{N} a_{i j}\left(T_{j}^{4}-T_{o}^{4}\right) \\
= & C_{P} \rho_{w} V\left(T_{\text {wout }}-T_{O}\right)+A_{i} h_{c i}\left(T_{i}-T_{r}\right)+A_{i} \bar{\varepsilon}_{i} \sigma\left(T_{i}^{4}-T_{O}^{4}\right)
\end{aligned}
$$

ここで、(A2)式に現われるそれぞれの温度には $T_{\text {win }}<T_{\text {wout }}<T_{O}$ 、ま た $T_{j}(j=1,2, \ldots, N)<T_{i}<T_{r}<T_{0}$ の関係があるので、雨辺の温度差の 备項はいずれも負である。このことは、井暃水は温度 $T_{0}$ の環境に対 して熱エネルギーが不足した状態、つまり環境と同じ温度の熱を吸 収することを、また、放射パネルは温度 $T_{0}$ の環境に対して放射エネ ルギーを放つのではなく受け取ることを表している。

(A2)式に対忍するエントロピー収支式は、エネルギーの場合と同 様に、まず(A1)式に対応するエントロピ一収支式を導いた後、両辺 に $\left(-A_{i} \bar{\varepsilon}_{i} \sigma \frac{4}{3} T_{O}^{3}\right)$ を加え放射のエントロピーの項を環境温度 $T_{O}$ 基準 の形する 6$\left.)^{3} 7\right)$ 。

$$
\begin{aligned}
A_{i} s_{R i} & +C_{p} \rho_{w} V \ln \frac{T_{w i n}}{T_{O}}+A_{i} \bar{\varepsilon}_{i} \sigma \frac{4}{3} \sum_{j=1}^{N} a_{i j}\left(T_{j}^{3}-T_{O}^{3}\right)+s_{g r p} \\
= & C_{p} \rho_{w} V \ln \frac{T_{\text {wout }}}{T_{O}}+A_{i} h_{c i} \frac{\left(T_{i}-T_{r}\right)}{T_{i}}+A_{i} \bar{\varepsilon}_{i} \sigma \frac{4}{3}\left(T_{i}^{3}-T_{o}^{3}\right)
\end{aligned}
$$

ここで、 $s_{R i}$ : 日射エントロピー $\left[\mathrm{W} /\left(\mathrm{m}^{2} \cdot \mathrm{K}\right)\right]$ である ${ }^{5)}$ 。また、(A3)式左 辺第 4 項の $s_{g r p}[\mathrm{~W} / \mathrm{K}]$ は、放射パネル表面に打ける放射の吸収によっ て生成されるエントロピーである。

エクセルギー収支式は、(A2)式から、(A3)式の雨辺に $T_{0}$ を乗じたも のを引くことで求められる。

$$
\begin{aligned}
& A_{i}\left\{R_{i}-s_{R i} T_{O}\right\}+C_{p} \rho_{w} V\left\{\left(T_{\text {win }}-T_{o}\right)-T_{o} \ln \frac{T_{w i n}}{T_{O}}\right\} \\
& +A_{i} \bar{\varepsilon}_{i} \sigma \sum_{j=1}^{N} a_{i j}\left\{\left(T_{j}^{4}-T_{o}^{4}\right)-T_{o} \frac{4}{3}\left(T_{j}^{3}-T_{o}^{3}\right)\right\}-s_{\text {grp }} \cdot T_{o} \\
& =C_{p} \rho_{w} V\left\{\left(T_{\text {wout }}-T_{O}\right)-T_{O} \ln \frac{T_{\text {wout }}}{T_{O}}\right\}+A_{i} h_{c i} \frac{\left(T_{i}-T_{r}\right)\left(T_{i}-T_{O}\right)}{T_{i}} \\
& +A_{i} \overline{\varepsilon_{i}} \sigma\left\{\left(T_{i}^{4}-T_{o}^{4}\right)-T_{o} \frac{4}{3}\left(T_{i}^{3}-T_{O}^{3}\right)\right\}
\end{aligned}
$$

左辺第 4 項の $\left(s_{g r p} \cdot T_{o}\right)$ が天井パネルでのエクセルギー消費の項であ る。(A4)式左辺第 2 項と右辺の第 1 項は、天井放射パネルに入る（出 る) 井戸水の持つエクセルギーである。 $T_{\text {win }}<T_{\text {wout }}<T_{O}$ ○場合でも \{\} 内は正である。これは井戸水が温度 $T_{O}$ の環境に対して冷エクセ ルギー（冷やす能力）を持っていることを示している。また同様に、 (A4)式左辺第 3 項と右辺第 3 項の放射エクセルギ一の項は、 $T_{i}$ と $T_{j}$ が $T_{0}$ より小さい場合でも正で、(2)式に示した放射エネルギーの向き が逆となっている。これは、それぞれの面から放射の泠エクセル ギー（物を冷やす能力）を持つ放射が放たれていることを示してい る。

（2002年 6 月 10 日原稿受理，2002年11月 1 日採用決定） 